\title{
ANALISIS IMPLEMENTASI PSAK 105 AKUNTANSI PEMBIAYAAN MUDHARABAH PADA BANK MUAMALAT CABANG BANDA ACEH
}

\author{
Dwi Andika Putra ${ }^{1}$, Muhammad Arfan ${ }^{* 2}$ \\ ${ }^{1,2}$ Program Studi Akuntansi Fakultas Ekonomi Universitas Syiah Kuala \\ e-mail: dwiandika91@gmail.com ${ }^{1}$, arfan_rais@ unsyiah.ac.id ${ }^{* 2}$
}

\section{* Corresponding Author}

\begin{abstract}
This study aims to find out how the mudharabah financing mechanism at Bank Muamalat Banda Aceh and whether the application of mudharabah accounting treatment at Bank Muamalat Banda Aceh is in accordance with PSAK 105. The research methodology used is a qualitative method using descriptive analysis techniques that provide an overview of the treatment mudharabah financing accounting at the Bank Muamalat Banda Aceh. The results of the analysis state that the accounting treatment of mudharabah financing at the Bank Muamalat Banda Aceh has been carried out well because the recording of transactions has been carried out in accordance with Financial Accounting Standards. However, at the beginning of the application of accounting, the recognition of the mudharabah contract was not regulated in PSAK 105. However, at that time the Bank Muamalat Banda Aceh recognized it first as an obligation because there had not yet been capital surrender to mudharib. In the application of accounting when recognition of purchases for acquisition prices is not regulated in PSAK 105. Bank Muamalat Banda Aceh recognizes it as an additional inventory. Mudharabah financing procedures at Bank Muamalat Banda Aceh are quite good and thorough so as to minimize the risk of financing. Starting from the request for financing, BI checking, decisions, realization, monitoring up to repayment to the bank as the owner of the funds
\end{abstract}

Keywords: Accounting Treatment, PSAK 105, Mudharabah Financing

\section{Pendahuluan}

Bank adalah badan usaha yang menghimpun dana dari masyarakat dalam bentuk simpanan dan menyalurkan kembali kepada masyarakat dalam bentuk kredit dan atau bentuk-bentuk lainnya dalam rangka meningkatkan taraf hidup rakyat banyak. Usaha perbankan meliputi tiga kegiatan, yaitu menghimpun dana, menyalurkan dana dan memberikan jasa bank lainnya (Kasmir 2014:14).

Bank merupakan lembaga keuangan dan keberadaan suatu lembaga tidak akan terlepas dari proses pencatatan akuntansi. Setiap lembaga keuangan maupun perbankan wajib melakukan pencatatan akuntansi atas aktivitasnya. Kegiatan yang dilakukan oleh lembaga keuangan syariah adalah penyaluran dana, penghimpun dana, dan produk yang berkaitan dengan jasa kepada masyarakat (Asmitha, 2011)

Berdasarkan Undang-Undang No. 21 Tahun 2008

pasal 1 ayat 2 tentang Perbankan Syariah disebutkan bahwa bank syariah adalah bank yang menjalankan kegiatan usahanya berdasarkan prinsip syariah dan menurut jenisnya terdiri atas bank umum syariah dan bank pembiayaan rakyat syariah.

Lembaga keuangan terbentuk karena adanya aktivitas mobilisasi dana dari masyarakat yang memberi pengaruh yang signifikan terhadap majunya perekonomian suatu negara. Lembaga keuangan merupakan lembaga perantara keuangan yang berfungsi sebagai sarana pendukung untuk menunjang perekonomian.

Perbedaan bank syariah dan konvensional yang sangat prinsipil adalah larangan riba atau bunga. Keberadaan akuntansi perbankan syariah sangat penting karena menentukan hak dan kewajiban pihakpihak yang terkait secara syar'i. Begitupun dengan bank muamalat yang pada awal berdiri memberlakukan pencatatan akuntansi seperti bankbank lain atau pun bank konvensional. Karena sebelum adanya peraturan mengenai standar akuntansi keuangan syariah, bank muamalat membuat suatu pos anggaran yang diberi istilah sebagai "pendapatan non 
halal", yakni pendapatan yang didapat dari transaksi perbankan konvensional. Hal ini berlaku sampai dengan tahun 2002 hingga akhirnya muncul Pernyataan Standar Akuntansi Syariah (selanjutnya ditulis PSAK) No 59.

Pernyataan Standar Akuntansi Keuangan (PSAK) adalah standar yang digunakan untuk pelaporan keuangan di Indonesia. PSAK digunakan sebagai pedoman akuntan untuk membuat laporan keuangan. Perlakuan akuntansi untuk produk pembiayaan mudharabah adalah PSAK 105 yang merupakan akuntansi untuk pengakuan, pengukuran, penyajian dan pengungkapan atas transaksi mudharabah (IAI, 2016).

Produk lembaga perbankan syariah adalah pembiayaan. Produk yang terdapat pada bank muamalat salah satunya adalah pembiayaan Mudharabah. Produk yang termasuk dalam pelayanan jasa ini menjadi salah satu produk yang banyak diminati masyarakat. Hal tersebut dikarenakan banyak masyarakat yang mengambil pinjaman pada bank muamalat. Bahkan masyarakat cenderung menggunakan pembiayaan mudharabah menjadi suatu bentuk modal investasi.

Secara umum, mudharabah dikenal sebagai akad kerja sama antara pemilik dana (shahibul maal) dan pengelola dana (mudharib) dalam mendirikan usaha tertentu untuk saling menguntungkan dimana besarnya proporsi bagi hasil berdasarkan kesepakatan bersama di awal akad. Pembiayaan mudharabah ini bermanfaat memberikan pengelolaan usaha terhadap pemilik modal dan manfaat berupa harta bagi si pengelola usaha.

Penyaluran pembiayaan mudharabah oleh LKS (Lembaga Keuangan Syariah) dinilai masih memiliki risiko yang cukup tinggi. Risiko yang tinggi disebabkan karena masih terdapat beberapa permasalahan dalam penyaluran pembiayaan mudharabah kepada masyarakat seperti kemungkinan adanya moral hazard dari mudharib yang menyebabkan berkurangnya return yang diterima shahibul maal. Selain moral hazard permasalahan lain adalah terjadinya informasi yang tidak berimbang antara shahibul maal dan mudharib seperti kurangnya informasi mengenai aturan-aturan pembiayaan mudharabah yang diterima mudharib dari shahibul maal dan juga informasi yang tidak transparan yang disampaikan oleh mudharib kepada shahibul maal.
Hal ini yang menyebabkan dalam penyaluran pembiayaan mudharabah pihak shahibul maal akan meminta jaminan agar mudharib tidak melakukan penyimpangan. Shaibul maal dapat meminta jaminan dari mudharib atau pihak ketiga, dan jaminan ini hanya dapat dicairkan jika mudharib terbukti melakukan pelanggaran terhadap hal-hal yang telah disepakati. Pembiayaan mudharabah merupakan salah satu produk pembiayaan bank muamalat yang paling berisiko karena bank sebagai pemilik dana bersedia memenuhi pembiayaan yang dibutuhkan oleh nasabahnya.

Salah satu aspek yang mendorong akuntansi dengan perspektif islam atau akuntansi syariah di Indonesia adalah dengan munculnya perbankan syariah. Bank syariah dalam usahanya memberikan pembiayaan selalu berlandaskan pada prinsip syariah, antara lain dengan tidak menggunakan sistem bunga untuk aktivitas perbankannya. Karena bunga merupakan jenis riba yang diharamkan oleh islam (Banindita, 2013).

\section{Kerangka Teoritis dan Kerangka Pemecah Masalah}

\section{Pembiayaan Mudharabah}

Pengertian pembiayaan berdasarkan UU No. 10 tahun 1998 tentang Perbankan Pasal 1 ayat 12, pembiayaan syariah adalah penyedia uang atau tagihan yang dapat dipersamakan dengan itu berdasarkan persetujuan atau kesepakatan antara bank dengan pihak lain yang mewajibkan pihak yang dibiayai untuk mengembalikan uang atau tagihan setelah jangka waktu tertentu dengan imbalan atau bagi hasil sesuai dengan kesepakatan.

Pembiayaan secara luas berarti financing atau pembelanjaan, yaitu pendanaan yang dikeluarkan untuk mendukung investasi yang telah direncanakan, baik dilakukan sendiri maupun dijalankan oleh orang lain. Dalam arti sempit, pembiayaan dipakai untuk mendefinisikan pendanaan yang dilakukan oleh lembaga pembiayaan, seperti bank syariah kepada nasabah (Arif, 2012:42)

Menurut Nurhayati (2015:128) mudharabah berasal dari kata addharby fl ardhi yaitu berpergian untuk urusan dagang. Disebut juga qiradh yang berasal dari kata alqhardu yang berarti potongan, karena pemilik memotong sebagian hartanya untuk diperdagangkan dan memperoleh sebagian 
keuntungan.

Dalam Pernyataan Standar Akuntansi Keuangan (PSAK) 105, disebutkan bahwa: "mudharabah adalah akad kerjasama antara dua pihak. Pihak pertama (pemilik dana) menyediakan seluruh dana, sedangkan pihak kedua (pengelola dana) bertindak selaku pengelola, dan keuntungan dibagi di antara mereka sesuai kesepakatan, sedangkan kerugian finansial hanya ditanggung oleh pemilik dana".

Secara terminologi, ulama fiqih mendefinisikan mudharabah atau qiradh dengan," pemilik modal menyerahkan modalnya kepada pekerja (pedagang) untuk diperdagangkan, sedangkan keuntungan dagang dibagi menurut kesepakatan bersama." Apabila terjadi kerugian dalam perdagangan tersebut, kerugian ini ditanggung sepenuhnya oleh pemilik modal (Chalish, 2012).

Menurut Fatwa DSN No: 07/DSN-MUI/2000, mudharabah (qiradh) adalah pembiayaan yang disalurkan oleh LKS kepada pihak lain untuk suatu usaha yang produktif. Bank yang bertindak sebagai shaibul maal (pemilik modal) membiayai 100\% kebutuhan suatu usaha, sedangkan nasabah yang bertindak sebagai mudharib hanya menyumbangkan keahlian atau keterampilannya.

\section{Jenis Mudharabah}

Mudharabah terbagi menjadi dua jenis, yaitu mudharabah mutlaqah (investasi tidak terikat) dan mudharabah muqayyadah (investasi terikat). Menurut Nurhayati (2015:130) mudharabah mutlaqah adalah pemilik dana memberikan kebebasan kepada pengelola dana dalam pengelolaan investasinya. Mudharabah ini disebut investasi tidak terikat. Selanjutnya, mudharabah muqayyadah adalah pemilik dana memberikan batasan kepada pengelola antara lain mengenai data, lokasi, cara dan objek investasi atau sektor usaha.

\section{Ketentuan Pembiayaan Mudharabah}

Berdasarkan fatwa DSN MUI No. 07/DSNMUI/IV/2000 terdapat ketentuan mengenai pembiayaan mudharabah. Ketentuan-ketentuan tersebut adalah :

a. Pembiayaan mudharabah adalah pembiayaan yang disalurkan oleh LKS kepada pihak lain untuk suatu usaha yang produktif.

b. Dalam pembiayaan ini LKS sebagai shahibul maal (pemilik dana) mempunyai $100 \%$ kebutuhan suatu usaha, sedangkan pengusaha (nasabah) bertindak sebagai mudharib atau pengelola usaha.

c. Jangka waktu usaha, tatacara pengembalian dana, dan pembagian keuntungan ditentukan berdasarkan kesepakatan kedua belah pihak (LKS dengan pengusaha).

d. Mudharib boleh melakukan berbagai macam usaha yang telah disepakati bersama dan sesuai dengan syari'ah; dan LKS tidak ikut serta dalam managemen perusahaan atau proyek tetapi mempunyai hak untuk melakukan pembinaan dan pengawasan.

e. Jumlah dana pembiayaan harus dinyatakan dengan jelas dalam bentuk tunai dan bukan piutang.

f. LKS sebagai penyedia dana menanggung semua kerugian akibat dari mudharabah kecuali jika mudharib (nasabah) melakukan kesalahan yang disengaja, lalai, atau menyalahi perjanjian.

g. Pada prinsipnya, dalam pembiayaan mudharabah tidak ada jaminan, namun agar mudharib tidak melakukan penyimpangan, LKS dapat meminta jaminan dari mudharib atau pihak ketiga. Jaminan ini hanya dapat dicairkan apabila mudharib terbukti melakukan pelanggaran terhadap hal-hal yang telah disepakati bersama dalam akad.

h. Kriteria pengusaha, prosedur pembiayaan, dan mekanisme pembagian keuntungan diatur oleh LKS dengan memperhatikan fatwa DSN.

i. Biaya operasional dibebankan kepada mudharib.

j. Dalam hal penyandang dana (LKS) tidak melakukan kewajiban atau melakukan pelanggaran terhadap kesepakatan, mudharib berhak mendapat ganti rugi atau biaya yang telah dikeluarkan.

\section{Rukun dan Syarat Pembiayaan Mudharabah}

Berdasarkan fatwa DSN MUI No. 07/DSNMUI/IV/2000 terdapat rukun dan syarat mengenai pembiayaan mudharabah. Rukun dan syarat tersebut adalah:

a. Penyedia dana (sahibul maal) dan pengelola (mudharib) harus cakap hukum. 
b. Pernyataan ijab dan qabul harus dinyatakan oleh para pihak untuk menunjukkan kehendak mereka dalam mengadakan kontrak (akad), dengan memperhatikan hal-hal berikut:

1) Penawaran dan penerimaan harus secara eksplisit menunjukkan tujuan kontrak (akad)

2) Penerimaan dari penawaran dilakukan pada saat kontrak.

3) Akad dituangkan secara tertulis, melalui korespondensi, atau dengan menggunakan cara- cara komunikasi modern.

c. Modal ialah sejumlah uang dan/atau aset yang diberikan oleh penyedia dana kepada mudharib untuk tujuan usaha dengan syarat sebagai berikut:

1) Modal harus diketahui jumlah dan jenisnya.

2) Modal dapat berbentuk uang atau barang yang dinilai. Jika modal diberikan dalam bentuk asset, maka asset tersebut harus dinilai pada waktu akad.

3) Modal tidak dapat berbentuk piutang dan harus dibayarkan kepada mudharib, baik secara bertahap maupun tidak, sesuai dengan kesepakatan dalam akad.

d. Keuntungan mudharabah adalah jumlah yang didapat sebagai kelebihan dari modal. Syarat keuntungan berikut ini harus dipenuhi:

1) Harus diperuntukkan bagi kedua belah pihak dan tidak boleh disyaratkan hanya untuk satu pihak.

2) Bagian keuntungan proporsional bagi setiap pihak harus diketahui dan dinyatakan pada waktu kontrak disepakati dan harus dalam bentuk prosentasi (nisbah) dari keuntungan sesuai kesepakatan. Perubahan nisbah harus berdasarkan kesepakatan.

3) Penyedia dana menanggung semua kerugian akibat dari mudharabah, dan pengelola tidak boleh menanggung kerugian apapun kecuali diakibatkan dari kesalahan disengaja, kelalaian, atau pelanggaran kesepakatan.

e. Kegiatan usaha oleh pengelola (mudharib), sebagai perimbangan (muqabil) modal yang disediakan oleh penyedia dana, harus memperhatikan hal-hal berikut:
1) Kegiatan usaha adalah hak eksklusif mudharib, tanpa campur tangan penyedia dana, tetapi ia mempunyai hak untuk melakukan pengawasan.

2) Penyedia dana tidak boleh mempersempit tindakan pengelola sedemikian rupa yang dapat menghalangi tercapainya tujuan mudharabah, yaitu keuntungan.

3) Pengelola tidak boleh menyalahi hukum syari'ah islam dalam tindakannya yang berhubungan dengan mudharabah, dan harus mematuhi kebiasaan yang berlaku dalam aktifitas itu.

Selanjutnya, berdasarkan fatwa DSN MUI No. 07/DSN-MUI/IV/2000 terdapat rukun dan syarat mengenai pembiayaan mudharabah. Rukun dan syarat tersebut adalah :

a. Mudharabah boleh dibatasi pada periode tertentu.

b. Kontrak tidak boleh dikaitkan (mu'allaq) dengan sebuah kejadian di masa depan yang belum terjadi.

c. Pada dasarnya, dalam mudharabah tidak ada ganti rugi, karena pada dasarnya akad ini bersifat amanah (yad al-amanah), kecuali akibat dari kesalahan disengaja, kelalaian, atau pelanggaran kesepakatan.

d. Jika salah satu pihak tidak menunaikan kewajibannya atau jika terjadi perselisihan di antara kedua belah pihak, maka penyelesaiannya dilakukan melalui Badan Arbitrasi Syari'ah setelah tidak tercapai kesepakatan melalui musyawarah.

Lamanya kerjasama dalam mudharabah tidak tentu atau tidak terbatas, tetapi semua pihak berhak untuk menentukan jangka waktu kontrak kerja dengan memberitahukan pihak lainnya. Namun, akad mudharabah dapat berakhir karena hal-hal sebagai berikut: (Nurhayati, 2015:133)

a. Dalam hal mudharabah tersebut dibatasi waktunya, maka mudharabah berakhir pada waktu yang telah ditentukan,

b. Salah satu pihak memutuskan untuk mengundurkan diri,

c. Salah satu pihak meninggal dunia atau kehilangan akal,

d. Pengelola dana tidak menjalankan amanahnya sebagai pengelola usaha untuk mencapai tujuan sebagaimana dituangkan 
dalam akad. Sebagai pihak yang mengemban amanah ia harus beritikad baik dan hati-hati,

e. Modal sudah tidak ada.

\section{Implementasi Mudharabah di Perbankan Syariah}

Menurut Salman (2012) penempatan dana di bank syariah dapat dilakukan dalam bentuk pembiayaan berakad jual beli maupun syirkah atau kerjasama bagi hasil. Jika pembiayaan berakad jual beli, maka bank akan mendapatkan margin pembiayaan. Dalam pembiayaan mudharabah, ada beberapa hal yang perlu diperhatikan oleh kedua belah pihak, yaitu:

a. Nisbah bagi hasil yang disepakati,

b. Tingkat keuntungan bisnis aktual yang didapat. Oleh karena itu, bank sebagai pihak yang memiliki dana akan melakukan perhitungan nisbah yang akan dijadikan kesepakatan pembagian pendapatan.

Nisbah bagi hasil merupakan faktor penting dalam menentukan bagi hasil di bank syariah. Sebab aspek nisbah merupakan aspek yang disepakati bersama antara kedua belah pihak yang melakukan transaksi. Untuk menentukan nisbah bagi hasil, perlu diperhatikan aspek-aspek: data usaha, kemampuan angsuran, hasil usaha yang dijalankan atau tingkat return aktual bisnis, tingkat return yang diharapkan, nisbah pembiayaan dan distribusi pembagian hasil.

Penentuan nisbah bagi hasil dibuat sesuai dengan jenis pembiayaan mudharabah yang dipilih. Ada dua jenis pembiayaan mudharabah yaitu: pembiayaan mudharabah mutlaqah dan pembiayaan mudharabah muqayyadah.

a. Nisbah bagi hasil pembiayaan mudharabah mutlaqah

Pembiayaan mudharabah mutlaqah adalah pembiayaan yang dilakukan dimana pemilik dana tidak meminta syarat, kecuali syarat baku untuk berlakunya akad mudharabah. Untuk ini, nisbah dibuat menggunakan metode expected profit rate atau epr. Expected profit rate diperoleh berdasarkan:

1) Tingkat keuntungan rata-rata pada industri sejenis,

2) Pertumbuhan ekonomi,

3) Dihitung dari nilai required profit rate (rpr) (nilai required profit rate diperoleh dengan rumus: $r p r=n \cdot V \quad(n=$ tingkat keuntungan dalam transaksi tunai: $v=$ jumlah transaksi dalam satu periode) yang berlaku di bank yang bersangkutan.

Dengan demikian, nisbah bagi hasil dapat dihitung dengan rumus sebagai berikut:

Nisbah bank $\quad=\frac{\text { Expected profit rate }(\text { epr }) x 100 \%}{\text { Expected return bisnis yang dibiayai (erb) }}$

Nisbah nasabah $\quad=100 \%$ Nisbah bank

Aktual return bank $=$ Nisbah bank + Aktual return bisnis

b. Nisbah bagi hasil pembiayaan mudharabah muqayyadah

Pembiayaan mudharabah muqayyadah adalah pemilik dana memberikan batasan kepada pengelola antara lain mengenai dana, lokasi, cara, dan objek investasi atau sektor usaha. Pada saat bank syariah mendapatkan nasabah yang ingin mengajukan pembiayaan mudharabah muqayyadah, biasanya nasabah menuntut adanya nisbah yang sebanding dengan bisnis tertentu. Pada akad pembiayaan mudharabah muqayyadah ini si pemilik dana menambah persyaratan di luar syarat kebiasaan akad mudharabah.

\section{Kerangka Pemecah Masalah}

Secara sistematis kerangka pemecah masalah dalam penelitian ini dapat digambarkan dengan bagan sebagai berikut:

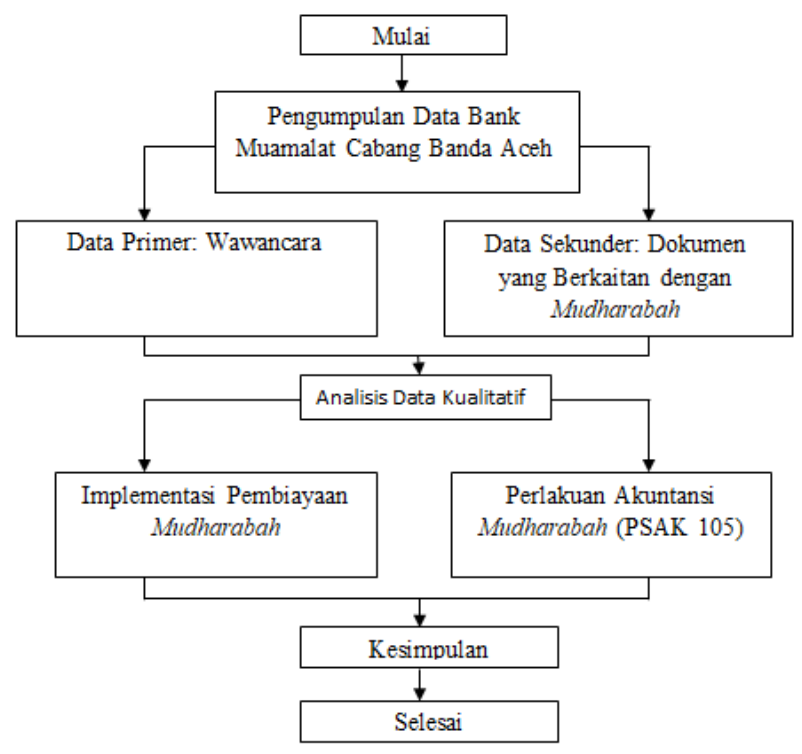

Gambar 2.1 Kerangka Pemecah Masalah 


\section{Metode Penelitian}

\section{Desain Penelitian}

Sekaran dan Bougie (2013:95) menyebutkan bahwa desain penelitian mencakup enam aspek sehingga data yang diperlukan dapat dikumpulkan dan dianalisis untuk memperoleh solusi, yaitu desain penelitian yang meliputi serangkaian pilihan pengambilan keputusan rasional, isu-isu yang berkaitan dengan keputusan mengenai tujuan studi (eksploratif, deskriptif, pengujian hipotesis), letaknya (yaitu konteks studi), jenis yang sesuai untuk penelitian (jenis investigasi), tingkat manipulasi dan kontrol peneliti (tingkat intervensi peneliti), aspek temporal (horizon waktu), dan level analisis data (unit analisis), adalah integral pada desain penelitian.

Jenis penelitian yang digunakan dalam penelitian ini adalah metode penelitian deskriptif kualitatif. Metode deskriptif menurut Sanusi (2014:13) adalah "desain penelitian yang disusun dalam rangka memberikan gambaran secara sistematis tentang informasi ilmiah yang berasal dari subjek atau objek penelitian". Selanjutnya, Sanusi (2014:13) juga menambahkan bahwa "penelitian deskriptif berfokus kepada penjelasan sistematis tentang fakta yang diperoleh saat penelitian dilakukan".

\section{Sumber Data}

Data adalah sekumpulan informasi yang dibutuhkan dalam sebuah penelitian. Sumber data dalam penelitian ini terdiri dari data primer dan data sekunder.

a. Data Primer

Data primer merupakan data yang diperoleh melalui observasi atau diperoleh secara langsung dari pihak bank Muamalat cabang Banda Aceh dengan melakukan wawancara mengenai pembiayaan mudharabah. Estenberg dan Sugiyono (2013:231) mengemukakan tiga jenis wawancara, yaitu (1) wawancara terstruktur, (2) semistruktur, dan (3) tidak terstruktur. Dalam penelitian ini jenis wawancara yang dilakukan adalah semistruktur yaitu sudah termasuk dalam kategori in-depth interview yang pelaksanaanya lebih bebas bila dibandingkan dengan wawancara terstruktur.

b. Data Sekunder

Data sekunder merupakan data yang diperoleh dari arsip atau dokumen yang berhubungan dengan pembiayaan mudharabah yang ada di
Bank Muamalat Cabang Banda Aceh.

\section{Metode Analisis}

Analisis data pada penelitian ini yaitu dengan menggunakan metode deskriptif. Data yang diperoleh akan disusun secara sistematis dan dianalisis secara kualitatif untuk mencapai kejelasan masalah yang akan dibahas. Penelitian deskriptif ini tidak membutuhkan hipotesis. Tujuannya ialah memberikan gambaran subjek penelitian sebagaimana adanya. Dalam hal ini, peneliti menganalisis dan menjelaskan hal-hal yang berkenaan dengan Bank Muamalat Cabang Banda Aceh terutama perlakuan akuntansi dan penerapan PSAK 105 (akad mudharabah).

Menurut Moleong (2012) analisis data adalah "proses mengatur urutan data, mengorganisasikannya ke dalam suatu pola, kategori dan uraian dasar". Definisi tersebut memberikan gambaran tentang berapa pentingnya kedudukan analisis data dilihat dari segi tujuan penelitian. Prinsip pokok penelitian kualitatif adalah menemukan teori dari data.

\section{Hasil Penelitian}

\section{Analisis Penerapan PSAK 105 Akuntansi Pembiayan Mudharabah di Bank Muamalat}

Berdasarkan penelitian penulis, perlakuan akuntansi pembiayaan mudharabah di Bank Muamalat mengacu pada PSAK 105. Adapun penyajiannya adalah sebagai berikut:

1) Perlakuan akuntansi akad mudharabah berdasarkan PSAK 105

a. Pencatatan persetujuan investasi
mudharabah
Dr. Kontra Komitmen Investasi Mudharabah
Kr. Kewajiban Komitmen Investasi Mudharabah

Penerapan akuntansi pada saat pengakuan akad mudharabah tidak diatur dalam PSAK 105, maka Bank Muamalat mengakuinya terlebih dahulu sebagai kewajiban karena belum terjadi penyerahan modal kepada mudharib.

\section{b. Pencatatan Pembelian \\ Dr. Persediaan/Aset Mudharabah Kr. Kas/ Rekening Supplier} $\mathrm{xxx}$

Penerapan akuntansi pada saat pengakuan pembelian sebesar harga perolehan tidak diatur 
dalam PSAK 105, maka bank mengakuinya sebagai penambah persediaan atau asset mudharabah.

c. Pencatatan penyerahan modal tahap pertama dalam bentuk tunai

$$
\begin{array}{ccc}
\text { Dr. Investasi Mudharabah } & \mathrm{xxx} & \\
\text { Kr. Rekening Mudharib } & \mathrm{xxx} \\
\text { Dr. Kewajiban Komitmen Investasi Mudharabah } & \mathrm{xxx} & \\
\text { Kr. Kontra Komitmen Investasi Mudharabah } & \mathrm{xxx}
\end{array}
$$

Penerapan akuntansi saat pengakuan penyerahan modal dalam bentuk tunai telah sesuai dengan PSAK 105 paragraf 12 yang menyatakan bahwa dana mudharabah yang disalurkan oleh pemilik dana diakui sebagai investasi mudharabah.

d. Pencatatan amortisasi keuntungan tanggungan

$$
\text { Dr. Keuntungan Mudharabah Tangguhan } \quad \mathrm{xxx}
$$

Kr. Keuntungan Penyerahan Modal Non-kas Mudharabah $\mathrm{xxx}$ Telah sesuai dengan PSAK 105 paragraf 13 yang menyatakan bahwa keuntungan tangguhan diamortisasi sesuai jangka waktu akad mudharabah.

1) Perhitungan penyusutan modal mudharabah nonkas (barang):

$$
\text { Nilai perolehan: } \operatorname{Rp} \frac{\mathrm{xxx}}{\mathrm{xxx}-+}
$$

2) Pada saat pembentukan penyusutan asset (modal nonkas) sebesar Rp. xxx

$$
\begin{aligned}
& \text { Dr. Penurunan Nilai Investasi Mudharabah } \quad \mathrm{xxx} \\
& \text { Kr. Akumulasi Penurunan Nilai Investasi Mudh (nonkas) }
\end{aligned}
$$

Penerapan akuntansi pada saat pengakuan dan pengukuran penyusutan asset (modal nonkas) perbulan telah sesuai dengan PSAK 105 paragraf 17 yang menyatakan bahwa dalam investasi mudharabah yang diberikan asset nonkas dan aset nonkas tersebut mengalami penurunan nilai pada saat atau setelah barang dipergunakan secara efektif dalam kegiatan usaha mudharabah, maka kerugian tersebut tidak langsung mengurangi jumlah investasi, namun diperhitungkan pada saat pembagian hasil.

e. Pengukuran investasi mudharabah:

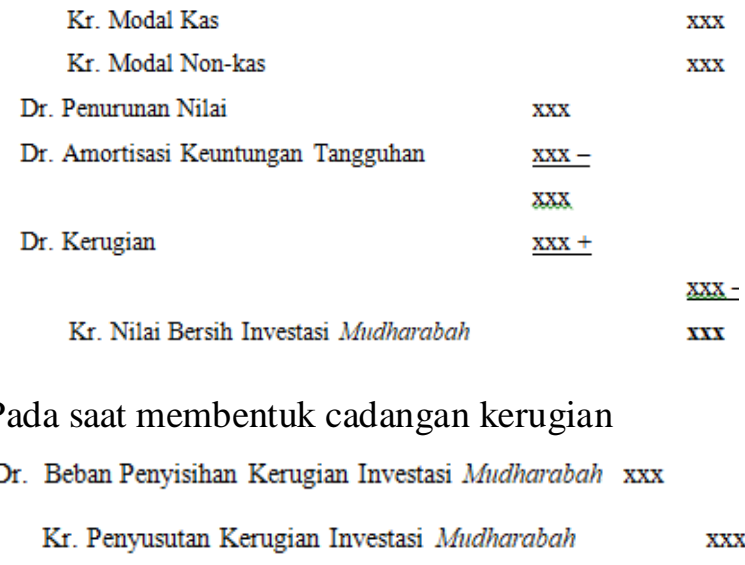

g. Pada saat penghapus bukuan PSAK 105 Paragraf 21 yang menyatakan bahwa kerugian yang terjadi dalam suatu periode sebelum akad mudharabah berakhir diakui sebaga kerugian dan dibentuk penyisihan investasi.

h. Diterima pengembalian modal mudharabah Dr. Rekening Mudharib

$\mathrm{xxx}$

\section{Kr. Investasi Mudharabah}

$\mathrm{xxx}$

Penerapan akuntansi pada saat pengakuan pengembalian modal mudharabah tunai telah sesuai dengan PSAK 105 paragraf 13 yang menyatakan bahwa investasi mudharabah dalam bentuk kas diukur sebesar jumlah yang dibayarkan.

i. Tidak mengembalikan modal kas pada saat jatuh tempo

$$
\begin{array}{lll}
\text { Dr. Piutang Mudharib } & \mathrm{xxx} & \\
\text { Kr. Investasi Mudharabah } & \mathrm{xxx}
\end{array}
$$

j. Saat pembayaran investasi jatuh tempo

$$
\begin{array}{lll}
\text { Dr. Kas/Rekening Mudharib } & \mathrm{xxx} & \\
& & \mathrm{xxx}
\end{array}
$$

PSAK 105 paragraf 19 yang menyatakan bahwa jika akad mudharabah berakhir sebelum atau saat akad jatuh tempo dan belum dibayar oleh pengelola dana, maka investasi mudharabah diaku sebagai piutang.

\section{Kesimpulan dan Saran}

\section{Kesimpulan}

Prosedur yang digunakan bank muamalat terhadap pembiayaan mudharabah cukup baik dan teliti sehingga dapat meminimalisir terjadinya risiko dalam pembiayaan, mulai dari pengajuan pembiayaan, BI checking, penandatanganan sampai dengan 
pencairan pembiayaan. Dari pembiayaan mudharabah terdapat manfaat yang dirasakan, yaitu bank dapat melakukan lending atau penyaluran dana yang telah terhimpun oleh bank muamalat dan digunakan untuk pembiayaan usaha atau proyek yang produktif. Dengan demikian, bank dan pengelola dana akan mendapatkan margin bagi hasil yang telah disepakati melalui akad mudharabah. Bagi pengelola dana (mudharib) akan mendapatkan tambahan modal usaha untuk lebih memproduktifkan dan mengembangkan usahanya tersebut.

Penerapan akuntansi syariah dalam produk bagi hasil pada pembiayaan mudharabah bank muamalat telah dilakukan dengan baik, karena pencatatan transaksi-transaksi sudah dilakukan sesuai standar akuntansi keuangan. Hal ini dapat dilihat dari pencatatan transaksi-transaksi yang dicatat oleh bank muamalat. Penerapan akuntansi baik pengakuan, pengukuran, penyajian dan pengungkapan pembiayaan mudharabah pada bank muamalat secara umum telah sesuai dengan PSAK 105 mengenai akuntansi mudharabah.

Akan tetapi, penerapan akuntansi pada saat pengakuan akad mudharabah ini tidak diatur dalam PSAK 105. Namun pada saat itu bank muamalat mengakuinya terlebih dahulu sebagai kewajiban karena belum terjadi penyerahan modal kepada mudharib dan pada saat penerapan akuntansi saat pengakuan pembelian sebesar harga perolehan tidak diatur dalam PSAK 105. Bank muamalat mengakuinya sebagai penambahan persediaan atau aset mudharabah.

\section{Keterbatasan}

Penelitian ini hanya dilakukan pada bank muamalat cabang banda aceh. Penulis sangat menyadari bahwa penelitian ini banyak memiliki kelemahan dan kekurangan karena minimnya data yang berhasil diperoleh di lapangan. Minimnya data ini terjadi karena data yang berupa angka-angka atau nominal tidak bisa dipublikasikan yang sudah menjadi ketentuan pihak bank.

\section{Saran}

Bank muamalat diharapakan lebih konsistensi dalam penerapan pengakuan dan pengukuran atas pencatatan transaksi mudharabah dengan ketentuan yang berlaku yaitu khususnya PSAK 105 yang menjelaskan mengenai akuntansi mudharabah. Meningkatkan kewaspadaan dalam menyalurkan dana kepada mudharib (pengelola dana). Bank muamalat harus melakukan penyebaran informasi mengenai bank syariah dengan melakukan publikasi atau pemberitahuan kepada masyarakat mengenai konsep syariah yang sejalan dengan prinsip perbankan yang memiliki keunggulan terbukti dapat bertahan didalam krisis global.

Untuk pihak bank muamalat agar dapat lebih membantu peneliti yang akan melakukan penelitian dengan lebih terbuka pada pihak-pihak yang ingin melakukan penelitian dan dapat mempermudah penulis untuk mengumpulkan data yang diperlukan dalam penelitian.

\section{Daftar Pustaka}

Arif, M. Nur Rianto Al (2012). DasarDasar Pemasaran Bank Syariah, Bandung:Alfabeta.

Asmitha (2011). Analisis perlakuan akuntansi pembiayaan gadai syariah PT Bank BRI Syariah, TBK Cabang Makassar, Skripsi Tidak Dipublikasikan. Makassar: Universitas Hasanudin.

Banindita (2013). Analisis penerapan PSAK 102 pada produk kepemilikan emas dan PSAK 107 pada produk gadai Emas di perbankan syariah (Studi Kasus Bank BNI Syariah Yogyakarta), Skripsi Tidak Dipublikasikan. Yogyakarta: Universitas Islam Negeri Kalijaga.

Bank Indonesia (1998). Undang-Undang Nomor 10 Tahun 1998 tentang Perubahan UndangUndang No. 7 Tahun 1992 tentang Perbankan. Jakarta: Gramedia.

Chalish, N (2012). Analisis Perlakuan Akuntansi Pembiayaan Mudharabah Pada PT. Bank Syariah Mandiri Kantor Cabang Makasar, Skripsi, Universitas Hasanuddin, Makasar.

Dewan Syariah Nasional MUI (2000). Fatwa DSN MUI No: 07/DSN-MUI/IV/2000 Tentang Pembiayaan Mudharabah. Jakarta: Dewan Syariah Nasional MUI [serial on line]. http://hukum.unsrat.ac.id/inst/dsn2000_7_mudh ar abah.pdf. [09 September 2015]. 
IAI (2016). Standar Akuntansi Keuangan Syariah 2017. Jakarta: IAI.

Kasmir, 2014. Analisis Laporan Keuangan, Edisi Pertama, Cetakan Ketujuh. Jakarta: PT. Rajagrafindo Persada.

Moleong, L. J (2012). Metode Penelitian Kualitatif. Bandung: PT Remaja Rosdakarya.

Nurhayati, S \& Wasilah, W (2015). Akuntansi Syariah di Indonesia. Jakarta: Salemba Empat.

Sanusi, A (2014). Metodologi Penelitian Bisnis. Jakarta: Salemba Empat.

Salman, Kautsar Riza. 2012. Akuntansi Perbankan Syariah Berbasis PSAK Syariah. Padang: Akademia Permata.

Sekaran, U. \& R. Bougie (2013). Research Methods for Business: Metodologi Penelitian untuk Bisnis. Buku 2. Edisi 4. Terjemahan Kwan Men Yon. Jakarta: Salemba Empat

Sugiyono \& Estenberg (2013). Metodologi Penelitian Kuantitatif, Kualitatif dan $R \& D$. Bandung: Alfabeta.

Undang-Undang No. 21 Tahun 2008, Tentang Perbankan Syariah, Pasal 1 Ayat 2. 